\title{
Skim milk powders with enhanced foaming and steam-frothing properties
}

\author{
Mary Ann Augustin ${ }^{1,2 *}$, Phillip Terence ClarkE ${ }^{1}$ \\ ${ }^{1}$ Food Science Australia, 671 Sneydes Road, Werribee, VIC 3030, Australia \\ ${ }^{2}$ School of Chemistry, Monash University, Clayton, VIC 3800, Australia
}

\begin{abstract}
The effects of citrate addition to milks on the stability of milk foams formed by two aeration processes, whipping at room temperature and by steam-frothing, were examined. Citrate addition (0.1-0.5 mol added citrate $\cdot \mathrm{kg}^{-1}$ milk solids non-fat) improved the whipping properties of milks reconstituted from conventional low-heat $\left(72{ }^{\circ} \mathrm{C}\right.$ for $\left.30 \mathrm{~s}\right)$ and high-heat $\left(85^{\circ} \mathrm{C}\right.$ for $\left.30 \mathrm{~min}\right)$ powders. This effect was attributed to the role of citrate in dissociating casein micelles. However, while citrate addition (0.1-0.2 mol added citrate $\cdot \mathrm{kg}^{-1}$ milk solids non-fat) improved the steamfrothing properties of milks reconstituted from conventional low-heat milk powder it did not improve those of milks made from corresponding high-heat milk powders. Similar effects of citrate addition on foaming and stream-frothing properties were obtained when the salts were added to skim milk concentrate prior to drying. The citrated milk powders are alternatives to physical blends of conventional skim milk powders and citrate salts for enhancing the foaming properties of milks at both low and high application temperatures.
\end{abstract}

milk powder / foaming / stream-frothing / casein micelle / citrate

摘要 - 增强脱脂奶粉的发泡性和蒸汽发泡性的研究.。本文研究了两个通风过程下, 即室温 下的摚打和蒸汽发泡, 添加柠檬酸盐对牛奶泡沫稳定性的影响。0.1-0.5 mol $\mathrm{kg}^{-1}$ (占非脂固 性物)柠檬酸盐添加量能够改善由常规低热处理 $\left(72^{\circ} \mathrm{C} 、 30\right.$ 秒) 和高热处理 $\left(85^{\circ} \mathrm{C} 、 30 \mathrm{~min}\right)$ 奶粉制成还原奶的摚打特性。产生这种作用的原因是柠檬酸盐使酪蛋白胶束解离。然而, 当 柠檬酸盐的添加量为 $0.1-0.2 \mathrm{~mol} \cdot \mathrm{kg}^{-1}$ (占非脂固性物) 时, 仅能够改善由低热处理奶粉制成 的还原奶的蒸汽发泡特性, 但是不能改善由高热处理奶粉制成的还原奶的蒸汽发泡性。如果 在干燥之前的浓缩脱脂乳中加入柠檬酸盐则获得了与上述试验类似的结果。与采用物理方 法将柠檬酸盐与低热或高热处理的脱脂粉混合相比较, 将柠檬酸盐加到干燥之前的浓缩孚和 生产柠檬酸盐乳粉是提高还原奶发泡性能的首选方法。

\section{乳粉 / 发泡性 / 蒸汽发泡性 / 酪蛋白胶束 / 柠檬酸盐}

Résumé - Poudres de lait écrémé ayant des propriétés moussantes améliorées lors de leur reconstitution à froid et à chaud. Les effets de l'addition de citrate au lait sur la stabilité des mousses de lait obtenues par deux procédés d'aération, à température ambiante ou à la vapeur, ont été étudiés. L'addition de citrate $\left(0,1-0,5 \mathrm{~mol} \cdot \mathrm{kg}^{-1}\right.$ de matière sèche non grasse du lait) améliorait les propriétés moussantes des laits reconstitués à partir de poudres conventionnelles "low-heat" $\left(72{ }^{\circ} \mathrm{C}-30 \mathrm{~s}\right)$ et "high-heat" $\left(85^{\circ} \mathrm{C}-30 \mathrm{~min}\right)$. Cet effet a été attribué au rôle du citrate dans la dissociation des micelles de caséine. Cependant, tandis que l'addition de citrate (à $0,1-0,2 \mathrm{~mol} \cdot \mathrm{kg}^{-1}$ de matière sèche non grasse du lait) améliorait les propriétés moussantes à la vapeur des laits

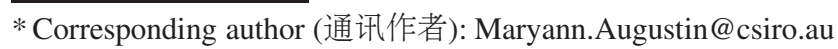


reconstitués à partir de poudre conventionnelle de lait "low-heat", elle n'améliorait pas celles des laits obtenus à partir des poudres "high-heat". Des effets similaires de l'addition de citrate sur les propriétés moussantes à froid et à la vapeur ont été obtenus quand les sels étaient ajoutés au concentré de lait écrémé avant séchage. La fabrication de poudre de lait enrichie en citrate est une alternative au mélange de poudre de lait écrémé conventionnelle et de sel de citrate pour améliorer les propriétés moussantes des laits à froid et à chaud.

\section{poudre de lait / propriété moussante / aptitude au moussage à la vapeur / micelle de caséine /} citrate

\section{INTRODUCTION}

Foam formation is important in the development of the texture of foods such as ice-cream, mousse, whipped toppings and meringues. Food proteins are used in a number of these food applications because of their ability to move to an interface and stabilize it. Many studies have examined the stability and interfacial properties of milk proteins, used on their own, or in combination with low molecular weight surfactants, for the stabilization of foams. These have shown that intrinsic properties of proteins (i.e. inherent nature of the protein) as well as extrinsic factors (e.g. $\mathrm{pH}$, ionic environment and heat) influence the formation and stability of a foam $[10,13$, 14, 20-22].

Both caseins and whey proteins contribute to the foaming properties of milk. Caseins are adsorbed at interfaces in preference to whey proteins [8]. It has been shown that $\beta$-casein, $\alpha$-lactalbumin and $\beta$-lactoglobulin are adsorbed at the airserum interface and that casein micelles are secondarily attached in milk foams made from pasteurized milk [3]. Studies on single component systems as well as binary protein systems using surface dilatation and surface shear rheology have indicated that while both caseins and whey proteins stabilize foams, they exhibit different behavior at interfaces. Random coil proteins such as $\beta$-casein are more rapidly adsorbed and spread at the interface compared to globular proteins such as $\beta$-lactoglobulin [16]. Analysis of foams made by whipping skim milk showed that there was preferential adsorption of $\beta$-casein over casein micelles and whey proteins under conditions where there was $\beta$-casein in the supernatant. However, in milk solutions with added calcium chloride, which prevented dissociation of the casein micelle, the interface was comprised of casein micelles and whey proteins only [21]. These results suggest that the caseins had to be available in the supernatant for adsorption to the interface. Improvement in foaming properties of milk was obtained with the addition of chelating agents such as hexametaphosphate [12] or EDTA [20] to milk systems. These chelating agents are known to cause release of caseins into the serum by dissociating the colloidal calcium phosphate within the casein micelles.

Whilst most foams are formed at low temperature, there is also interest in the foaming properties of milk at high temperature, for example, in the foams produced by steam injection for hot milk-based beverages. Proteins have a major role in the stabilization of steam-frothed milks. Poor steam-frothing properties were obtained in milks with high levels of free fatty acids resulting from lipolysis of milk. The mono- and di-glycerides, formed along with free fatty acids during lipolysis of fat are considered to be responsible for the poor steam-frothing properties of milk containing fat $[4,7]$. The risks associated with lipolysis are markedly reduced when skim milk is used for the preparation of cappuccinos.

In this work, we examine the effects of citrate addition to milk on the stability of 
milk foams formed by two aeration processes - whipping at room temperature and by steam-frothing. The feasibility of citrate addition during milk powder manufacture for the production of milk powder with enhanced foaming and steam-frothing properties was also tested.

\section{MATERIALS AND METHODS}

\subsection{Materials}

Skim milk was obtained from a local dairy company. Skim milk powders produced on several occasions were obtained from Tatura Milk Industries, Tatura, Victoria. Analytical grade chemicals were used in laboratory trials. These were trisodium citrate from $\mathrm{BDH}$ and citric acid, calcium chloride and disodium hydrogen phosphate from Ajax Chemicals. Food grade citric acid and tripotassium citrate used for the production of modified milk powders were from Proscience while citric acid and trisodium citrate (analytical grade) were from Unilab.

\subsection{Manufacture of milk powders}

For the production of conventional skim milk powders, the skim milk was preheated, concentrated to $\sim 450 \mathrm{~g}$ solids $\cdot \mathrm{kg}^{-1}$ in an APV pilot-scale double effect falling film evaporator and dried to $\sim 960 \mathrm{~g}$ solids $\cdot \mathrm{kg}^{-1}$ using a Niro Production Minor spray dryer (Niro A/S, Soborg, Denmark) [5]. Low-heat $\left(72{ }^{\circ} \mathrm{C} / 30 \mathrm{~s}\right)$ or high-heat $\left(85{ }^{\circ} \mathrm{C} / 30 \mathrm{~min}\right)$ preheat treatments were given to the skim milk for the production of low-heat and high-heat milk powders respectively.

Where modified milk powders (hereafter called citrated milk powders) were made, a mixture of citric acid and its trisodium/tripotassium salt was added to a skim milk concentrate (350$450 \mathrm{~g}$ solids $\cdot \mathrm{kg}^{-1}$ ) prior to drying. Levels of addition used were $0.1-0.5$ mol added citric acid/citrate salt per $\mathrm{kg}$ milk solids non-fat (MSNF). These levels were chosen as preliminary trials carried out indicated that these amounts of citrate could improve foaming and steam-frothing properties of milk. From the preliminary trials, it was also estimated that molar ratios of 1:4, 1:5 and 1:10 of citric acid to trisodium/tripotassium citrate were required to maintain the natural $\mathrm{pH}$ $(6.6 \pm 0.1)$ of milk powder on reconstitution to milk to $100 \mathrm{~g}$ solids $\cdot \mathrm{kg}^{-1}$ with 0.1 , 0.2 and $0.5 \mathrm{~mol} \cdot \mathrm{kg}^{-1} \mathrm{MSNF}$ respectively.

\subsection{Preparation of milks}

Milks at the required total solids were reconstituted by dispersion of milk powder in distilled water. When $\mathrm{pH}$-adjustment was required, this was achieved by the addition of $\mathrm{HCl}$ or $\mathrm{NaOH}$. When the preparation of milks with added salts $\left(\mathrm{Na}_{2} \mathrm{HPO}_{4}\right.$ or citric acid/trisodium citrate mixtures or $\mathrm{CaCl}_{2}$ ) was required, these were added at levels of $0.1-0.5 \mathrm{~mol} \cdot \mathrm{kg}^{-1} \mathrm{MSNF}$. All solutions were equilibrated at $\sim 20{ }^{\circ} \mathrm{C}$ for $1 \mathrm{~h}$ prior to foaming experiments and 3-4 h at $4{ }^{\circ} \mathrm{C}$ prior to steam-frothing experiments.

\subsection{Measurement of foaming properties}

The method of Phillips et al. [15] was adapted. Foams were formed by whipping $100 \mathrm{~mL}$ of reconstituted milk in a Sunbeam Mixmaster (Model MX/AC) with a small bowl (MX18S18) (Sunbeam Corporation, Campsie, New South Wales, Australia). A setting of 12 was used. This setting corresponded to a beater speed of $1000 \mathrm{rpm}$ and a bowl speed of $110 \mathrm{rpm}$. The bowl speed was kept constant by using a Parvalux Electric Motor (CMG Electric Motors, Ringwood, Victoria, Australia).

Milk solutions were whipped for $20 \mathrm{~min}$. After whipping, foam samples 
were carefully scooped out with a spatula, placed into an open-ended cylindrical weighing vessel and weighed. Foam overrun was calculated as follows:

Foam overrun $(\%)=$

[(Wt. $100 \mathrm{~mL}$ solution-Wt. $100 \mathrm{~mL}$ foam)/

Wt. $100 \mathrm{~mL}$ foam] $\times 100$.

For the measurement of foam stability, a weighing vessel containing the foam which had been whipped for 20 min was allowed to drain into a measuring cylinder for a further $30 \mathrm{~min}$. Foam stability was calculated as follows:

Foam stability $(\%)=$

[(Wt. $100 \mathrm{~mL}$ foam-Wt. liquid drained)/

Wt. $100 \mathrm{~mL}$ foam] $\times 100$.

For foaming experiments at room temperature where the foaming properties were measured as a function of $\mathrm{pH}$ and citrate level addition, there were single measurements done on each powder sample at each of the various pH's tested. Duplicate measurements of foam properties of powders previously carried out showed that the differences between measurements on the same sample were generally $<5 \%$. Representative data from one data set has been given in the paper. Similar trends were obtained when replicate experiments were done on different occasions using milks produced at different times of the year.

\subsection{Determination of steam-frothing properties}

A Rancilio S10/CD Cappuccino machine was used for the assessment of steam-frothing properties of milks. The steam pressure was preset at $1.25 \mathrm{kPa}$. A four-holed steam nozzle (hole diameter $2 \mathrm{~mm}$ ) was positioned so that the holes in the nozzle were below the surface of the milk. Steam was injected into $200 \mathrm{~mL}$ of milk in a $2 \mathrm{~L}$ stainless steel jug for $30 \mathrm{~s}$. The steam pressure at the end of frothing was $1.1 \mathrm{kPa}$ and the temperature of the milk was $\sim 65^{\circ} \mathrm{C}$. After steam-frothing, the milk was decanted into a $500 \mathrm{~mL}$ measuring cylinder. After $5 \mathrm{~min}$ and $10 \mathrm{~min}$ from the start of the frothing, the volume of the milk at the liquid froth interface plus and the total volume (i.e. froth plus the liquid) was noted. The steam-frothing value (SFV), as previously defined by Deeth and Smith [7], was used except that measurements at 5 min were used. Foam volume was also measured at $10 \mathrm{~min}$ and taken as an indicator of stability.

Steam-frothing value $\left(\mathrm{SFV}_{5 \mathrm{~min}}\right)=$ (Total volume - Liquid volume)/ Liquid volume] $\times 100$.

Foam value $\left(\mathrm{FV}_{10 \text { min }}\right)=[$ Total volume - Liquid volume].

For steam frothing experiments, triplicate measurements were done on each sample.

\section{RESULTS AND DISCUSSION}

\subsection{Foaming properties of milks}

The foaming properties of reconstituted milks were examined as a function of $\mathrm{pH}$ and the preheat treatment given during powder manufacture. The effects of addition of selected salts on the modification of foaming properties were also determined.

\subsubsection{Effects of $p H$ and preheat treatment of milk}

The foaming properties of milk are given in Table I. The foam overrun at the natural $\mathrm{pH}$ of milks $(\mathrm{pH} 6.6 \pm 0.1)$ reconstituted from low-heat powders and highheat powders ranged from $760-860 \%$ and 790-920\% respectively while the foam stability values were $55-60 \%$ and $55-80 \%$. 
The differences in the foaming properties of milks given different preheat treatments during powder manufacture were more marked at lower $\mathrm{pH}$ compared to that at natural $\mathrm{pH}$. Lowering the $\mathrm{pH}$ from the natural $\mathrm{pH}$ of milk to $\mathrm{pH} 5.5$ improved foaming properties of both milks although the improvements were more marked when a high-heat treatment was used. Increasing $\mathrm{pH}$ also improved foaming properties.

The variation in the foaming properties of milk obtained on three occasions was expected. It has been reported that foam volume produced from different samples of commercial skim milk varied by $15 \%$ and it was suggested that seasonal variation in protein content and composition do not by themselves significantly account for the fluctuations in the foaming properties of skim milk [1]. It has been postulated that the availability of $\beta$-casein and differences in the ionic composition of milk were responsible for differences observed [1]. It is also possible that low concentrations of surface-active peptides present in milk [8] were a contributory factor.

The effects of $\mathrm{pH}$ on foaming properties are in line with our previous work where milks of similar concentration (100 g solids $\left.\cdot \mathrm{kg}^{-1}\right)$ and conditions of foaming were used [20]. With decreasing $\mathrm{pH}$, the major effect is an increase in foam overrun whereas foam stability is more improved at high $\mathrm{pH}$. The foaming properties of milk is an interplay of many factors including the availability of surface active material that has the ability to lower the surface tension, the rheological properties of the interface due to interactions between the proteins at the interface and the viscosity of the solution. Depending on the $\mathrm{pH}$, the relative importance of these factors can vary. The enhanced foaming properties observed on decreasing $\mathrm{pH}$ from the natural $\mathrm{pH}$ to $\mathrm{pH} 5.5$ may be rationalized in terms of a change in the availability of individual caseins. As the $\mathrm{pH}$ is lowered, micellar calcium phosphate dissociates and individual caseins are liberated from casein micelles $[6,19]$. At lower $\mathrm{pH}$ 's close to the isoelectric point, the charge on the proteins is reduced, hence protein-protein interactions are promoted and this stabilizes the film. The increase in foaming properties of milk as $\mathrm{pH}$ is increased above the natural $\mathrm{pH}$ of milk may also be attributed to an increased availability of caseins as $\mathrm{pH}$ is increased. Increasing levels of casein were found to solubilize as the $\mathrm{pH}$ was increased from 6.7 to 7.1 [2]. At high $\mathrm{pH}$, it is probable that the viscosity effects have a major contributory effect on enhancing foam stability. When lower concentrations of skim milks ( $14 \mathrm{~g}$ solids $\left.\cdot \mathrm{kg}^{-1}\right)$ and a shorter whipping time were used, whippability was similar with increasing $\mathrm{pH}$ beyond pH 6.0 [21]. However, in these dilute milk systems where there was insufficient calcium in the serum to maintain caseins in the micellar state, reducing $\mathrm{pH}$ from $\mathrm{pH} 6$ to $\mathrm{pH} 4.5$ reduced whippability [21].

There are similar profiles in the trend of foaming-pH profiles of low-heat and highheat milk powders. The foaming properties at corresponding $\mathrm{pH}$ 's above and below the natural $\mathrm{pH}$ of the milks are marginally higher for high-heat treated milks. A major difference between high-heat and low-heat milk powder is the presence of denatured whey protein attached to the casein micelle, thus changing the nature of proteinprotein interactions and the surface of the micelle. In addition it is well known that denaturation of whey protein increases its ability to hold water. These heat-induced changes in milk are expected to affect foaming properties but the relative contribution of various heat-induced changes to foaming properties is hard to know. Studies on the effects of heat treatments of caseinate and whey protein isolate solutions have shown that heat treatment improved foaming properties [17]. However, heat treatment of milk did not affect foaming capacity of milk [9]. Others have suggested that the effect of heat treatment was of 
Table I. Effects of preheat treatment during milk powder manufacture on the foaming properties of reconstituted milk ( $96 \mathrm{~g}$ solids $\cdot \mathrm{kg}^{-1}$ ).

\begin{tabular}{|c|c|c|c|c|c|}
\hline \multicolumn{3}{|c|}{ Low-heat milk powder } & \multicolumn{3}{|c|}{ High-heat milk powder } \\
\hline pH & Foam overrun (\%) & Foam stability (\%) & pH & Foam overrun (\%) & Foam stability (\%) \\
\hline \multicolumn{6}{|c|}{ Batch 1} \\
\hline 5.6 & 1020 & 65 & 5.5 & 1150 & 70 \\
\hline 6.2 & 810 & 55 & 6.2 & 840 & 55 \\
\hline 6.4 & 780 & 50 & 6.4 & 850 & 55 \\
\hline 6.6 & 760 & 55 & 6.6 & 820 & 55 \\
\hline 6.9 & 760 & 55 & 6.9 & 850 & 60 \\
\hline 7.3 & 760 & 60 & 7.3 & 870 & 65 \\
\hline 7.8 & 780 & 75 & 7.8 & 850 & 80 \\
\hline \multicolumn{6}{|c|}{ Batch 2} \\
\hline 5.8 & 1080 & 65 & 5.7 & 1120 & 65 \\
\hline 6.1 & 930 & 60 & 6.1 & 960 & 55 \\
\hline 6.4 & 880 & 60 & 6.3 & 900 & 60 \\
\hline 6.7 & 830 & 55 & 6.5 & 790 & 55 \\
\hline 7.1 & 820 & 60 & 6.9 & 930 & 60 \\
\hline 7.3 & 710 & 75 & 7.2 & 910 & 70 \\
\hline 7.9 & 820 & 90 & 7.5 & 790 & 80 \\
\hline & & & 7.9 & 870 & 90 \\
\hline \multicolumn{6}{|c|}{ Batch 3} \\
\hline 5.5 & 1090 & 75 & 5.5 & 1130 & 80 \\
\hline 5.7 & 1000 & 70 & 5.8 & 1020 & 70 \\
\hline 6.1 & 1000 & 60 & 6.1 & 890 & 65 \\
\hline 6.7 & 860 & 60 & 6.3 & 790 & 60 \\
\hline 6.9 & 770 & 60 & 6.7 & 920 & 80 \\
\hline 7.3 & 750 & 65 & 7.2 & 880 & 80 \\
\hline 7.7 & 820 & 90 & & & \\
\hline
\end{tabular}

Low-heat and high-heat skim milk powders were made from the same batch of milk that was obtained on three different occasions. Foam overrun was measured after $20 \mathrm{~min}$ of whipping. Foam stability was that of the whipped foam after $30 \mathrm{~min}$. These are single measurements for each $\mathrm{pH}$ from the 3 batches of milk.

secondary importance compared to conditions of aeration [11].

\subsubsection{Effects of added salts}

The effects of added citrate or phosphate $\left(0.21 \mathrm{~mol}\right.$ added salt $\left.\cdot \mathrm{kg}^{-1} \mathrm{MSNF}\right)$ on the foaming properties of milk (960 g solids $\cdot \mathrm{kg}^{-1}$ ) reconstituted from high-heat milk powder are given in Figure 1. Similar trends were obtained when the effects of added salts were determined for another batch of milk powder. Both salts increased the foam overrun and foam stability although the addition of citrate was more effective for increasing foaming properties over the $\mathrm{pH}$ range examined. The addition of a lower concentration of salt $(0.11 \mathrm{~mol}$ added phosphate or citrate $\cdot \mathrm{kg}^{-1} \mathrm{MSNF}$ ) also produced better foams than milks without added salt but the effect was less pronounced (data not shown). The addition of $\mathrm{CaCl}_{2}$ at a level of $0.21 \mathrm{~mol}$ added salt $\cdot \mathrm{kg}^{-1}$ MSNF totally depressed 



Figure 1. Effects of added salt $\left(0.21 \mathrm{~mol}\right.$ added phosphate or citrate $\left.\cdot \mathrm{kg}^{-1} \mathrm{MSNF}\right)$ on the foaming properties of milks ( $96 \mathrm{~g}$ solids $\cdot \mathrm{kg}^{-1}$ ) reconstituted from high-heat skim milk powder. Foam overrun was measured after 20 min of whipping; foam stability was that of the whipped foam after $30 \mathrm{~min}$ standing ( $\mathbf{\Lambda}$ : milk with no additives; $\mathbf{\square}$ : milk with added phosphate; $\bullet$ : milk with added citrate).

foam formation in the range $\mathrm{pH} 5.5-7.8$ and stable foam was only obtained at pH 5.2.

At the levels of salts used, it is known that added calcium decreases serum casein content whereas the addition of phosphate or citrate which complex calcium has the opposite effect [18]. The improved foaming properties of milks with added phosphate or citrate and the depression of foam formation with added calcium can be attributed to changes in the availability of soluble caseins. The observed effects of added calcium complexing salts on foam- ing properties of milk corroborate those observed previously [12,20,21].

\subsection{Steam-frothing properties of milks}

Figure 2 shows the effect of preheat treatment and citrate addition on the steam-frothing properties of milk (100 g solids $\left.\cdot \mathrm{kg}^{-1}\right)$. Low-heat milks had superior steam-frothing properties compared to high-heat milks and the addition of citrate was only effective for 



Figure 2. Effects of heat treatment and added citrate on the steam-frothing properties of milks $(100 \mathrm{~g}$ solids $\cdot \mathrm{kg}^{-1}, \mathrm{pH}$ 6.7) reconstituted from skim milk powder. Steam-frothing value was measured after 5 min of frothing; foam stability was the foam volume of the frothed milk after 10 min standing (average data for 2 sets of powders; $\bullet$ : milks made with low-heat milk powder; $\mathbf{m}$ : milks made with high-heat milk powder). 
improving the steam-frothing properties of low-heat milks. Others have found that while pasteurization of milk increased steam-frothing properties, the use of higher temperatures $\left(>72{ }^{\circ} \mathrm{C}\right)$ did not further enhance steam-frothing properties [7]. In this work, citrate addition at 0.1-0.2 mol added citrate $\cdot \mathrm{kg}^{-1}$ MSNF improved steam-frothing properties of milks that were given a low-heat treatment. However, others have found that addition of lower levels of citrate to full-cream milk $\left(1.5 \mathrm{~g} \cdot \mathrm{kg}^{-1}\right.$ added trisodium citrate which corresponds to $\sim 0.05 \mathrm{~mol}$ added citrate $\cdot \mathrm{kg}^{-1}$ MSNF) did not produce a marked change in steam-frothing properties [4]. The difference could be due to the higher level of citrate used in this study.

The observation that the effects of added citrate on the steam-frothing properties were dependent on the pre-heat treatment given to milk may be attributed to differences in the protein states in the two milks. In the high-heat treated milk, the majority of the whey proteins are denatured and hence the air-water interface formed during frothing will be different from that formed when low-heat milk is steam-frothed. Previous work has shown that high-heat treatment causes $\sim 70 \%$ whey protein denaturation [20]. It was also shown that although there was a similar degree of casein dissociation in low-heat and high-heat treated milks caused by the addition of a chelating agent (EDTA), the dissociation of the highheat milk also caused dissociation of denatured whey protein from the micelle [4], leaving a micelle with different properties from a micelle in high-heat treated milk.

The fact that citrate addition improved the foaming properties of a high-heat treated milk at room temperature but not under conditions of stream-frothing suggests that the conditions used for foaming influence the functionality of the milk ingredients. Although the composition and speciation of the proteins in the high-heat treated milks with added citrate will be the same at the start of the low temperature foaming and steam-frothing experiments, the interfacial layer formed will be different under the different conditions used for foaming and steam-frothing. This could be due to the altered kinetics of adsorption of the surface-active material at the interface as well as changes to the milk proteins due to the exposure of the milk to increased temperature during steam-frothing. Differences in the interfacial properties will in turn influence the stability of the foams made at different temperatures.

\subsection{Citrated powders}

\subsubsection{Manufacture}

Milk powders with added citrate were prepared where citrate was added to the concentrate prior to drying. Citrated milk concentrates were dried immediately after addition of the citrate. It was apparent that the citrated concentrates were more prone to thickening and hence holding of concentrate should be avoided.

\subsubsection{Foaming properties}

The foam overrun and stability of milks reconstituted from conventional milk powders and citrated milk powders are shown in Figures 3-4. In separate experiments, when powders were made on different occasions, the trends in the data were the same although the absolute values varied due to the seasonal variation in the milk supply. The results indicate that milks reconstituted from citrated low-heat skim milk powders $(0.2$ and 0.5 mol added citrate $\cdot \mathrm{kg}^{-1} \mathrm{MSNF}$ ) had higher overrun, compared to conventional milk powders over the range of $\mathrm{pH}$ studied. Foam stability was also improved over the $\mathrm{pH}$ range studied with citrate addition to low-heat milk. However, at $\mathrm{pH}>7$ citrated milk 

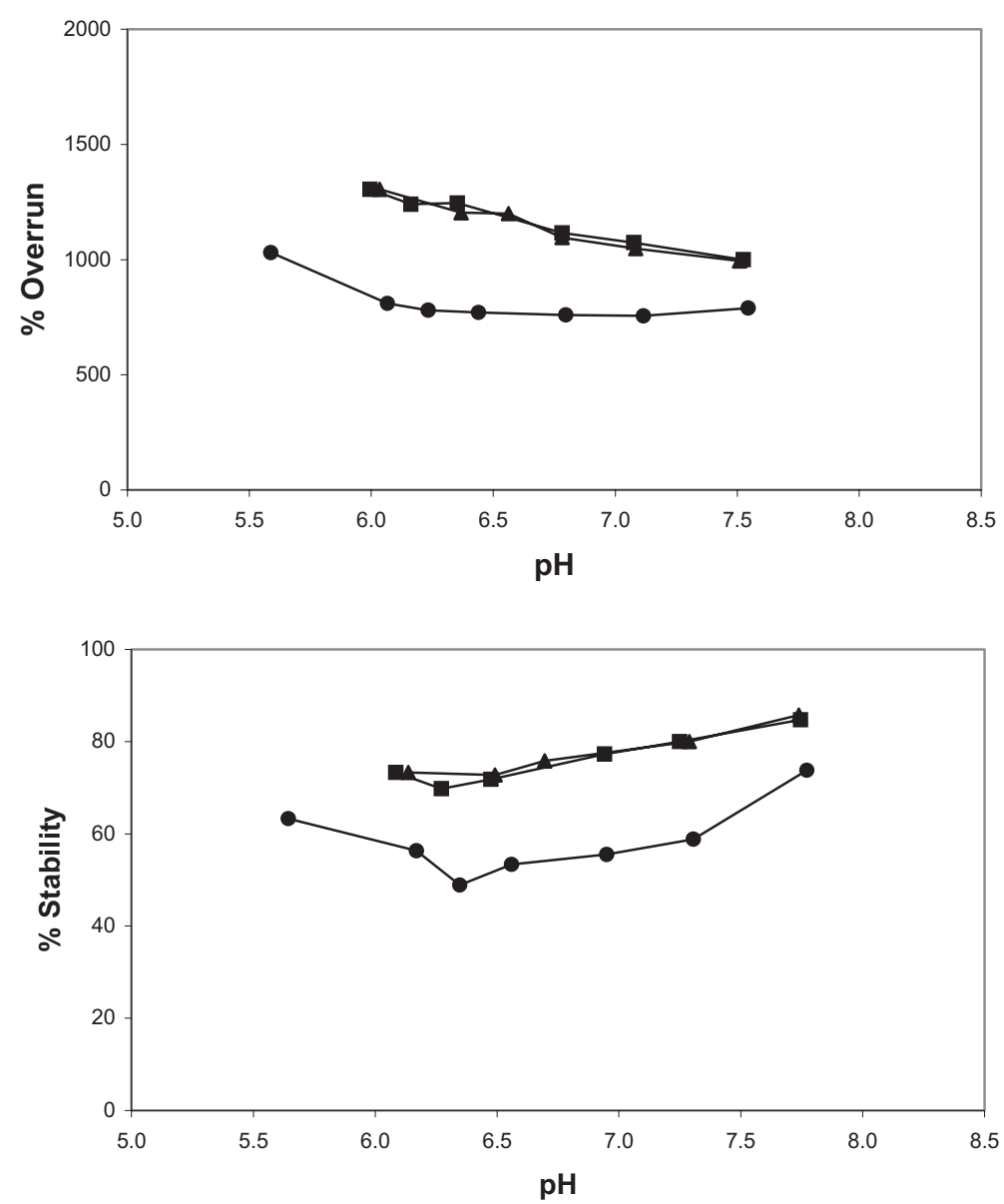

Figure 3. Effects of added salt $\left(0.2 \mathrm{~mol}\right.$ added citrate $\left.\cdot \mathrm{kg}^{-1} \mathrm{MSNF}\right)$ on the foaming properties of milks ( $96 \mathrm{~g}$ solids $\cdot \mathrm{kg}^{-1}$ ) reconstituted from low-heat skim milk powder. Foam overrun was measured after 20 min of whipping; foam stability was that of the whipped foam after $30 \mathrm{~min}$ standing $(\bullet$ : low-heat skim milk powder; $\mathbf{\square}$ : citrated low-heat skim milk powder with $0.2 \mathrm{~mol}$ added citrate $\cdot \mathrm{kg}^{-1}$ MSNF; $\mathbf{\Lambda}$ : low-heat skim milk powder with $0.2 \mathrm{~mol}$ added citrate $\cdot \mathrm{kg}^{-1} \mathrm{MSNF}$ added after reconstitution).

powder with high levels of added citrate (0.5 mol $\cdot \mathrm{kg}^{-1} \mathrm{MSNF}$ ) were less stable than conventional low-heat milk powder. These trends in foaming properties of low-heat citrated milk powders with high levels of added citrate $\left(0.5 \mathrm{~mol} \cdot \mathrm{kg}^{-1} \mathrm{MSNF}\right)$ were similar to those for high-heat citrated milk powders (data not shown). These results demonstrate that citrated powder could be used as an alternative to adding citrate directly to milk, as the enhancement in foaming properties obtained by adding citrate to concentrate prior to spray-drying was of a similar magnitude to that obtained by the addition of citrate to skim milk after reconstitution. 

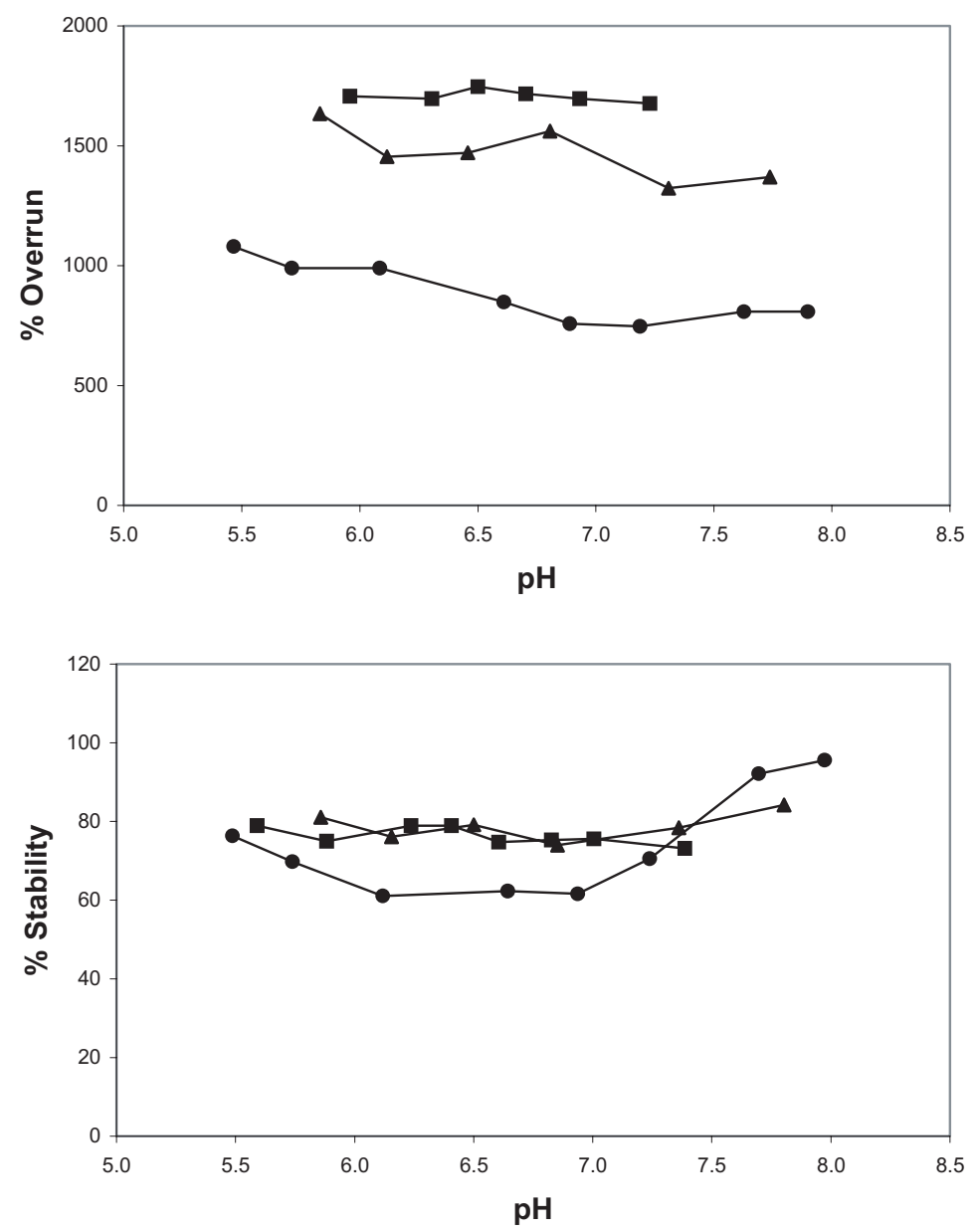

Figure 4. Effects of added salt ( $0.5 \mathrm{~mol}$ added citrate $\left.\cdot \mathrm{kg}^{-1} \mathrm{MSNF}\right)$ on the foam overrun of milks $\left(96 \mathrm{~g}\right.$ solids $\left.\cdot \mathrm{kg}^{-1}\right)$ reconstituted from low-heat skim milk powder. Foam overrun were measured after $20 \mathrm{~min}$ of whipping; foam stability was that of the whipped foam after $30 \mathrm{~min}$ standing ( $\bullet$ : low-heat skim milk powder; $\mathbf{n}$ : citrated low-heat skim milk powder with $0.5 \mathrm{~mol}$ added citrate $\cdot \mathrm{kg}^{-1} \mathrm{MSNF}$;

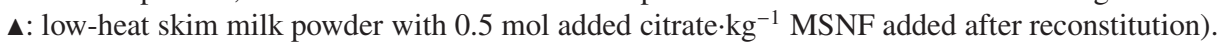

\subsubsection{Steam-frothing properties}

The addition of citrate at levels of 0.1 mol added citrate $\cdot \mathrm{kg}^{-1} \mathrm{MSNF}$ to milk concentrate during powder manufacture enhanced the steam-frothing properties of milk, as shown in Figure 5. This confirms that the citrate addition during powder manufacture produced similar effects to the addition of citrate to milk reconstituted from milk powders.

\section{CONCLUSION}

The improved foaming properties of citrated powders are attributed to the effects of added citrate on the dissociation of 




Figure 5. Comparison of the steam-frothing properties of milk ( $100 \mathrm{~g}$ solids $\left.\cdot \mathrm{kg}^{-1}, \mathrm{pH} 6.7\right)$ reconstituted from conventional and citrated low-heat milk powders and milks to which citrate was added after reconstitution. Steam-frothing value was measured after $5 \mathrm{~min}$ of frothing; foam stability was the foam volume of the frothed milk after 10 min standing. a: skim milk powder (no additives); b: skim milk powder (citrate added after reconstitution); c: citrated skim milk powder. The level of citrate used was $0.1 \mathrm{~mol}$ added citrate $\cdot \mathrm{kg}^{-1}$ MSNF. In citrated milk powders, citric acid/trisodium citrate was used. When citrate was added to milk, tripotassium citrate was used. Average of triplicate measurements of powders made on two occasions.

casein micelles. Citrated powders are an alternative to physical blends of conventional skim milk powders and citrate salts for enhancing the foaming properties at both low and high temperatures.

Acknowledgements: Assistance provided by B. Aitken, R. Birkett and L.J. Cheng is gratefully acknowledged. The research was funded by the Dairy Research and Development Corporation (now Dairy Australia).

\section{REFERENCES}

[1] Anderson M., Brooker B.E., Dairy Foams, in: Dickinson E., Stainsby G. (Eds.), Advances in food emulsions and foams Elsevier Applied Science, London, GB, 1988, pp. 221-255.

[2] Anema S.G., Klostermeyer H., Heatinduced, pH-dependent dissociation of casein micelles on heating reconstituted skim milk at temperatures below $100{ }^{\circ} \mathrm{C}, \mathrm{J}$. Agric. Food Chem. 45 (1997) 1108-1115.
[3] Brooker B.E., Observations on the air-serum interface of milk foams, Food Microstruct. 4 (1985) 289-296.

[4] Buchanan R.A., Lipolysis and frothing of milk, Aust. J. Dairy Technol. 20 (1965) 62-66.

[5] Clarke P.T., Kieseker F.G., A pilot scale preheating system for the treatment of milk and whey, CSIRO Res. Q. 46 (1986) 86-89.

[6] Dalgleish D.G., Law A.J.R., pH-induced dissociation of bovine casein micelles. 1 . Analysis of liberated caseins, J. Dairy Res. 55 (1988) 529-538.

[7] Deeth H.C., Smith C.A.D., Lipolysis and other factors affecting the stream-frothing capacity of milk, Aust. J. Dairy Technol. 38 (1983) 14-19.

[8] Dickinson E., Mauffret A., Rolfe S.E., Woskett C.M., Adsorption of interfaces in dairy systems, J. Soc. Dairy Technol. 42 (1989) 18-22.

[9] El-Samragy Y.A., Hansen C.L., McMahon D.J., Production of ultrafiltered skim milk retentate powder. II. Functional properties, J. Dairy Sci. 76 (1993) 2886-2890. 
[10] Foegeding E.A., Luck P.J., Davis J.P., Factors determining the physical properties of protein foams, Food Hydrocoll. 20 (2006) 284-292.

[11] Hoffmann W., Wieczorek A., Borcherding $\mathrm{K}$., Investigation in formation and stability of milk foam, Kiel Milchwirt. Forschung. 54 (2002) 243-255.

[12] Kelly P.M., Burgess K.J., Foaming properties of milk protein concentrate prepared by ultrafiltration, Ir. J. Food Sci. Technol. 2 (1978) 93-104.

[13] Kinsella J.E., Phillips L.G., Structure functional relationships in food proteins, film and foaming behaviour, in: Kinsella J.E., Souice W. (Eds.), Food Proteins, American Oil Chemists' Society, Champaign, Illinois, USA, 1989, pp. 72-77.

[14] Patino J.M.R., Delgado M.N.D., Fernández J.A.L., Stability and mechanical strength of aqueous foams containing food proteins, Colloid Surface A. 99 (1995) 65-78.

[15] Phillips L.G., Haque Z., Kinsella J.E., A method for the measurement of foam formation and stability, J. Food Sci. 52 (1987) 1074-1077.

[16] Ridout M.J., Mackie A.R., Wilde P.J., Rheology of mixed beta-casein/betalactoglobulin films at the air-water interface, J. Agric. Food Chem. 52 (2004) 3930-3937.
[17] Schmidt K., McNeill V., Effects of heat treatments on the functional properties of caseinate and whey protein isolate solution, Milchwissenschaft 48 (1993) 3-6.

[18] Udabage S., McKinnon I.R., Augustin M.A., Mineral and casein equilibria in milk: effects of added salts and calcium chelating agents, J. Dairy Res. 67 (2000) 361-370.

[19] Van Hooydonk A.C.M., Hagedoorn H.G., Boerrighter I.J., pH-induced physicchemical changes of casein micelles in milk and their effect on renneting. 1 . Effect of acidification on physico-chemical properties, Neth. Milk Dairy J. 40 (1986) 281-296.

[20] Ward B.R., Goddard S.J., Augustin M.A., McKinnon I.R., EDTA-induced dissociation of casein micelles and its effect on foaming properties of milk, J. Dairy Res. 64 (1997) 495-504.

[21] Zhang Z., Dalgleish D.G., Goff H.D., Effect of $\mathrm{pH}$ and ionic strength on competitive protein adsorption to air/water interfaces in aqueous foams made with mixed proteins, Colloid Surface B. 34 (2004) 113-121.

[22] Zhang Z., Goff H.D., Protein distribution at air interfaces in dairy foams and ice cream as affected by casein dissociation and emulsifiers, Int. Dairy J. 14 (2004) 647-657. 